Article

\title{
Freedom of Mass Communication in the Digital Age in the Case of the Internet: "Freedom House" and the USA Example ${ }^{\dagger}$
}

\author{
Ayhan Dolunay ${ }^{1, *}$ (1) , Fevzi Kasap ${ }^{2}$ and Gökçe Keçeci ${ }^{3}$ \\ 1 Legal Advisor and Lecturer of Faculty of Communication, Near East University, Nicosia 99138, Cyprus \\ 2 Head of Radio and Television Department, Faculty of Communication, Near East University, \\ Nicosia 99138, Cyprus; fevzi.kasap@neu.edu.tr \\ 3 Dean of Faculty of Communication, Near East University, Nicosia 99138, Cyprus; gokce.kececi@mail.com \\ * Correspondence: ayhan.dolunay@neu.edu.tr \\ + The study is developed from the paper (Internet Freedom within the Framework of Democracy and Human Rights \\ Education: "Freedom House?" and the USA Example) introduced at the 6th Educational Conference on \\ Education (IC-ED 2017), in 16-18.08.2017 by Dolunay \& Keçeci.
}

Received: 28 August 2017; Accepted: 24 September 2017; Published: 7 October 2017

\begin{abstract}
Similar to various other disciplines, there have been significant changes and developments in the communication domain during the first quarter of the 21st century. The use of the Internet, which is considered as a vital communication tool in modern times, and often referred to as the "digital information communication era/digital era", has become increasingly popular and has experienced significant development and change. Such change has led to a transformation in the concept of "new media" and has extended its scope to include the concept of social media; thus, the Internet has become an essential aspect of life due to its characteristics of facilitating information access and socialization. The "Internet" can be interpreted in different ways, including an important mass communication tool that serves the purposes of globalization (within McLuhan's Global Village Theory); or an important tool in the simulation universe (within Bourdieu's Simulation Universe Theory); or a new public sphere (within Habermas's Public Sphere Theory). However, in addition to its benefits, the "harm" has also become an issue that is subject to analysis as much as the legal responsibility dimension of the concept. From this perspective, various countries around the world have started to use different practices in relation to the access and use of terms in political and legal aspects. In particular, "the Internet censorship" has become vital in the determination of limits, since crossing such lines could damage the fundamental principles of human rights and democracy. The American organization, Freedom House, which conducts regular studies to identify the status of relevant limitations as well Internet freedoms and publishes reports accordingly, is a leading supervisory body when it comes to "the freedoms" on a global scale. Based on the independence of analysis conducted in various countries by Freedom House on the practices of those countries from an international political and economic perspective based on political rights and human rights; at the specific level, this study assesses the analysis of Freedom House conducted on the USA in different periods within the framework of decisions made by American courts and statements from politicians. In general, this study aims to discuss the possibility of Freedom House maintaining its activities in an independent structure. This study has a multi-disciplinary nature, with communication science focusing on the concept of the Internet as a basic communication tool; with the jurisprudence due to the assessment of legal arrangements used for internet censorship, given by other geographical example, with a particular focus on the example of the USA and related court decisions; and political science due to the regulation of the subject and the preparation of related laws by the government and interpretation of the matter by politicians. Additionally, pursuant to the data collected in relation with all disciplines, the status of Internet freedom in the USA, which is indicated in the reports of Freedom House to be one of the countries with the most freedom, and objectivity
\end{abstract}


analysis of Freedom House will be performed through the content analysis (legal analysis and comparative analysis) method.

Keywords: mass communication; internet freedom; censorship; freedom house; USA

\section{Introduction}

After important progress was made in the years following academic research that began in the 1960s, the research started to take a different form with the increased usage of computer technology—especially in the 1990s—subsequently "the social media", a originally a term that emerged in the 1970s, has been further developed and presently occupies an important place under the title of "the new Internet media". The Internet has become "the most powerful" mass media among other forms of communication (e.g., telegraph, telephone, radio, television, etc.), each of which were considered revolutionary at the time of their invention, and has been one of "the irreplaceable elements" of our lives since the 2000s.

According to the theory proposed by Marshall McLuhan—the well-known media specialist-the world will become "a global village" as a result of the development of the mass media (Rigel, 2005: 17). This has come to fruition after the development of the Internet and social media; people around the world now have the ability to communicate with each other instantaneously and it has reached a point where people can constantly be aware of the locations of other people, as well as what they are doing.

On the other hand, particularly in the digital era, the notions of "the new media/the social media" have an important place in people's lives, and it has become an issue that has been researched extensively in terms of the advantages and disadvantages of the Internet, along with the legal dimension. In this context, different kinds of practices for access and usage have been implemented politically and legally by various countries around the world.

When it is used correctly, Internet censorship, which is the one of the most common practices, provides important services such as blocking various malicious content and/or removing such contents. However, when supervision of the Internet is in question, the related supervision and restrictions being implemented should not contravene freedom of expression. This is because freedom of expression, being under the responsibility of the countries that are based on democracy and human rights and have democratic governance mechanism, now also covers the Internet.

\section{Aim, Scope and Method}

As a result of the development and transformation of the Internet, questioning the "advantages and disadvantages" of this communication tool that is perceived to have an "irreplaceable" quality has led to the implementation of supervision and restrictions. Supervision of content and censoring (blocking and/or removing the content) content that is deemed to be "illegal" are the primary practices being performed. On the other hand, it should be reiterated, that due to its high importance that "Internet censorship" by the countries (modern governments) that are based on democracy and human rights, that these must not damage the freedom of expression—within the frame of responsibility for enabling "the freedom of expression".

Within the scope of McLuhan's "Global Village" and Habermas' "Public Sphere", this study focuses on the concept of "the Internet". Also, in the frame of the Internet censorship and the freedom of expression balance, which should be established sensitively, the politicians' discourse and the practices (the laws in-effect/withdrawn/in-draft and the court decisions), will be analyzed, particularly within the USA and in comparison to other examples from European countries.

In this regard, the concept of "the American Dream", which means that the USA is "a country of freedoms", will be evaluated within the framework of Baudrillard's Theory of the Simulation Universe, and it will be researched whether there is a lack of clarity in the practice of Internet freedoms. 
On the other hand, it will be questioned to what extent reports (particularly related to the USA) published by "Freedom House" —an internationally prestigious watchdog organization which makes assessment/publishes reports related to freedoms such as "democracy practices", "freedom of the press", "freedom of the Internet" and makes observations as "free-partly free-not free" for the countries by grading the related aspects and which is even used as the basis for determining whether foreign investments are made or not-actually reflect "the truth". It will also be questioned whether it is possible for Freedom House, as an organization with American origins, to function in an independent structure.

This study bears assumes an interdisciplinary approach, including several scientific fields such as: the Science of Communication - because of the notion of the Internet mentioned in this study is one of the basic mass media; Jurisprudence-because there will be a focus on whether Internet censorship is performed in accordance with the legal acts in the United States in comparison to various other countries and because court decisions related to this point will be analyzed; Political Sciences-because the related laws are prepared by the parliament while the aforesaid issue is regulated through the law as well as the fact that the issue is debated by politicians, and also because Freedom House describes itself as "a non-governmental organization" that has had a close connection with politics and politicians in the light of crucial data from the day it was founded to the present and because it is an organization that supports the USA's politics/foreign policies.

In this study, related regulations legislated by the USA Government and the related decisions made by the USA courts are analyzed via a method of law analysis; data about the approaches taken by the USA authorities (politicians) towards the related decisions are analyzed via the method of content analysis; and data about research and reports related to the example of the American organization Freedom House in comparison with other countries are analyzed via the method of comparative analysis.

\section{Democracy, Freedom of Expression and Historical Situation in the USA}

\subsection{Concepts of Democracy and Freedom of Expression}

The term "democracy" originates from a combination of the words "demos" and "kratos", which means "the people's power". Furthermore, it has assumed a different meaning in the modern era and is now used to describe different functions.

Even though the concept of democracy has been discussed for centuries, it assumed an important place in political theory after the emergence of modern thought. As elements such as individual freedom, equality, rationality, etc. form the basis of modern thought, they are also the basis of democracy [1]. It is relative difficult to define the concept because of its multi-dimensional character. However, it is possible to depict its general structure by focusing on three essential elements: Individual, society and government.

Primarily, a balance is established between individual freedoms and social freedoms. Because individuals are important, and social priorities are basically created by the individuals in collaboration, which take precedence over individuals' demands. However, this is not sufficient to depict the general frame of democracy. The concept of the government is also important because individual and social rights should be protected and secured by democratic organizations that have public power [2].

Montesquieu, one of the democracy theorists, stated that the freedom of expression is the most important freedom, and he emphasized the importance of a free environment [3]. This is because the freedom of expression can only become functional and the democratic organizations will be able to continue and develop when a free environment is provided [4].

On the other hand, it must be stated that the individuals in democratic societies are not completely free to express whatever they want; otherwise, this could be damaging to the society. If individuals express whatever they think, it could obstruct others' freedom, and it could also lead to disruption to the government in power or even its destruction [5]. Nevertheless, it is important to sensitively 
draw a line between allowing individuals to express whatever they think and the thoughts they can express freely. This is because democracy and democratic society would not exist if these two abstract lines converge; on the contrary, there would be "a dictatorship with limited or no individual and social rights" or "a weak governance in which individual and social rights get damaged frequently".

According to the common view, the freedom of expression is "sine qua non" of the democracy and "a basic human right". This is because the freedom of expression makes it possible to form an opinion in the society and for the discussion related to public issues to exist (Freedom of Expression in Democratic Societies-A Liberal Perspective). The basic method to question and to detect who and/or which view is right in democratic societies is called "public discussion" (Freedom of Expression in Democratic Societies-A Liberal Perspective), and it can exist only in those societies that have freedom of expression.

The point is put in order through Article 1 in the United States Constitution-again, because of its significant importance. Furthermore, it is stated that the "freedom of expression and freedoms" cannot be restricted through legislations made by congress:

"Congress shall make no law respecting an establishment of religion, or prohibiting the free exercise thereof; or abridging the freedom of speech, or of the press; or the right of the people peaceably to assemble, and to petition the Government for a redress of grievances".

Because this study will primarily focus on the example of the United States, it is important to provide a brief overview on the irony that the United States is regarded as "the most liberal country in the world" and it was established on the values of "the American Dream".

\subsection{Analysis of "Human Rights" in the History of the USA}

As stated, the freedom of expression as a basic human right is sine qua non of democracy. However, there is frequently no, or at least restricted, freedom of expression in non-democratic structures. There must primarily be the "right to live" and "equality" in order to have freedom of expression. Therefore, it is necessary to provide a brief overview on the history of modern America, regarded as the motherland of human rights, and to analyze the right-to-live and equality.

In the process that started with discovery of America by Christopher Columbus in 1492, significant migration occurred from "the old world" to "the new world". Within this process, vast numbers of Native Americans were killed, which began with the Napituca Massacre in 1539, and this continued with the Mabila Massacre (1540), Tiguex Massacre (1541-1542), Acoma Massacre (1599); and many other incidents until 1826. In 28 May 1830, through the Indian Removal Act signed by Andrew Jackson-the President of America at that time-the policy of forcing the Indians to emigrate was legitimized. Although this law was intended to deport the natives from their land areas to the west through agreements, the reality was that this was achieved through force. Thousands of natives were deported from their own land forcefully, during which some of them died while being transported in chains, and this forced migration has been called "the trail of tears" in history.

Another example that portrays the American Dream in a negative light is that of slavery. In the middle of the 1800s, even though the economy was gradually turning to industry in other parts of America, it was based on agriculture in the southern regions, which were dominated by the system of slavery. While this system was banned in some states, Abraham Lincoln promised that he would remove slavery from the entire country and was duly elected as President. Due to concerns over his commitment to abolish slavery, 11 of the southern states declared their independence under the leadership of Jefferson Davis. This led to the Civil War between the Northern and Southern States between 1861 and 1865. Although this was devastating for both sides, the North was ultimately victorious; however, Lincoln, who has been called "the best American President", was assassinated by a Southern soldier in 1865 [6]. Consequently, the United States overcame this separation and most importantly, the agriculture-based economy in the South was transformed, slavery was banned and those freed from slavery were given the right to vote. 
On the other hand, Native Americans and Southern Americans (black people in the South) were not the only ones who were "being doomed to" live in conditions that compromised their human rights. It is also important to mention the struggles of African Americans living in North America had throughout history. Their arrival in America dates back to 1869. At that time, there was an increase in the mortality rates of English migrants who were unable to cope with the harsh conditions in Jamestown; thus, indentured workers from Africa were brought to work in the region. These people, who were described as "Colored People" throughout America were forced to live separately from "White People" for a long time. Moreover, they were only allowed to perform menial work such as in clothing shops and were even separated from others on public transportation. Statements such as "Whites only" or "Coloreds only" were written on the transportation vehicles demonstrated the level of discrimination that existed.

African Americans were treated as second or even third-class citizens; thus, this led to various battles in which they were successful. For instance, in the case of Brown vs. Board of Education (1954), racial discrimination in public schools was found to be unconstitutional. Also, in the case where Rosa Parks refused to relinquish her seat to a white passenger in Montgomery, Alabama, which resulted in her arrest, the American Supreme Court decided that the racial discrimination in the Alabama bus system was unconstitutional (1956).

In the following period, efforts by the African American civil rights movement led to the "the Civil Rights Legislation (1964)"-which legally removed racial discrimination in the USA, which resulted from the struggles of the civil rights movement under the leadership of Martin Luther King. The legislation was proposed by John F. Kennedy, the USA President at that time, although he too was subsequently assassinated before it could be signed. Thus, it was ultimately signed by his successor, President Lyndon B. Johnson.

This legislation was an important turning point for the African Americans in the USA; although providing equality in life conditions has proven to be more of a long-term problem. At the beginning of the 1970s, Rap Music (Rythmic American Poetry) emerged as an expression of their difficult life conditions in ghettos, and was another indicator of this situation.

The long fight to "have human rights" at the beginning and for equal life conditions later has achieved results in the fields of culture, art and sports for the African Americans (e.g., singers Nat King Cole and Whitney Houston; NBA basketball players Michael Jordan and Kobe Bryant; scientist W.E.B. Du Bois; author Toni Morrison, etc.). The ultimate example of this progress was, Barrack Obama being elected as the USA President, subsequently serving two terms between 2009 and 2017.

On the other hand, Donald Trump-elected as President in 2017-has initiated the scenario in which democracy and human rights (which had appeared to be showing signs of settling in American society, not as "the American Dream" but, at least, in terms of appearance) are becoming obscured through divisive discourse. While criticizing the media harshly, Trump has drawn attention with his controversial discourses on subjects such as the deportation of Mexican immigrants, his goal of constructing a vast border wall between Mexico and North America, and his decision to label all Muslims as "terrorists".

This is the true reality of "democracy and human rights" in American history, which is contrast to the tenets of the "American Dream". On the other hand, with the development of the Internet and New Media, it is essential that the United States should be discussed in terms of present freedoms.

Media and the Internet, called the alternative media, have become very important tools for assuring and improving freedoms. Initially, the media (newspapers, radio, television, etc.) criticized policies of the authorities on social freedoms by fulfilling its critical duty; thus, the media made a significant contribution to assuring fundamental rights and freedoms. However, because media channels are largely dependent on a certain executive (patron) and because these executives primarily aim to "get along with" the authorities, it has never been possible for the media to exist in a completely free and critical structure. On the other hand, the Internet is a medium through which more critical and 
free views can be published due to new websites that have been created that have no economic concerns tied to larger corporations in the mainstream media In other words, the emancipatory potential of the Internet is significantly higher.

Nevertheless, in modern America, censorship of critical approaches or negative views against government policy published on the Internet is being performed without people noticing. As will be mentioned later, although the United States is presented as a relatively free country by the authorities and the reporters of the Freedom House, it actually applies countless illegal censorship. In this regard, it is firstly necessary to focus on Freedom House-the global freedom auditor, which defines the USA as 'quite free', and to research its official discourse and structure as a background.

\section{Analysis of the Role of "Freedom House" as the Monitor of Mass Communication}

\section{1. "Official" Mission}

Freedom House is USA-based organization that grades democracy, freedom of the press and Internet-based freedoms in countries; furthermore, it recommend various non-pecuniary sanctions for restrictions (declaring them anti-democratic, giving low scores, etc.) within its own criteria. In the "About Us" section of their own website, the following description is provided:

"Freedom House is an independent watchdog organization dedicated to the expansion of freedom and democracy around the world. We analyze the challenges to freedom, advocate for greater political rights and civil liberties, and support frontline activists to defend human rights and promote democratic change. Founded in 1941, Freedom House was the first American organization to champion the advancement of freedom globally. We recognize that freedom is possible only in democratic political environments where governments are accountable to their own people; the rule of law prevails; and freedoms of expression, association, and belief, as well as respect for the rights of minorities and women, are guaranteed. More than 2.5 billion people live in countries that Freedom House designates "Not Free", more than a third of the globe's population ... We advocate for U.S. leadership and collaboration with like-minded governments to vigorously oppose dictators and oppression...". [7]

According to the scores they assign under the subjects of "democracy", "freedom of the press" and "freedom of the Internet", they categorize the countries as "free"- "partly free"- "not free". Related qualifications are involved in Freedom House's annual reports. In the freedom of the Internet report for 2016, assessments and scores are provided for a total of 65 countries (Figure 1).

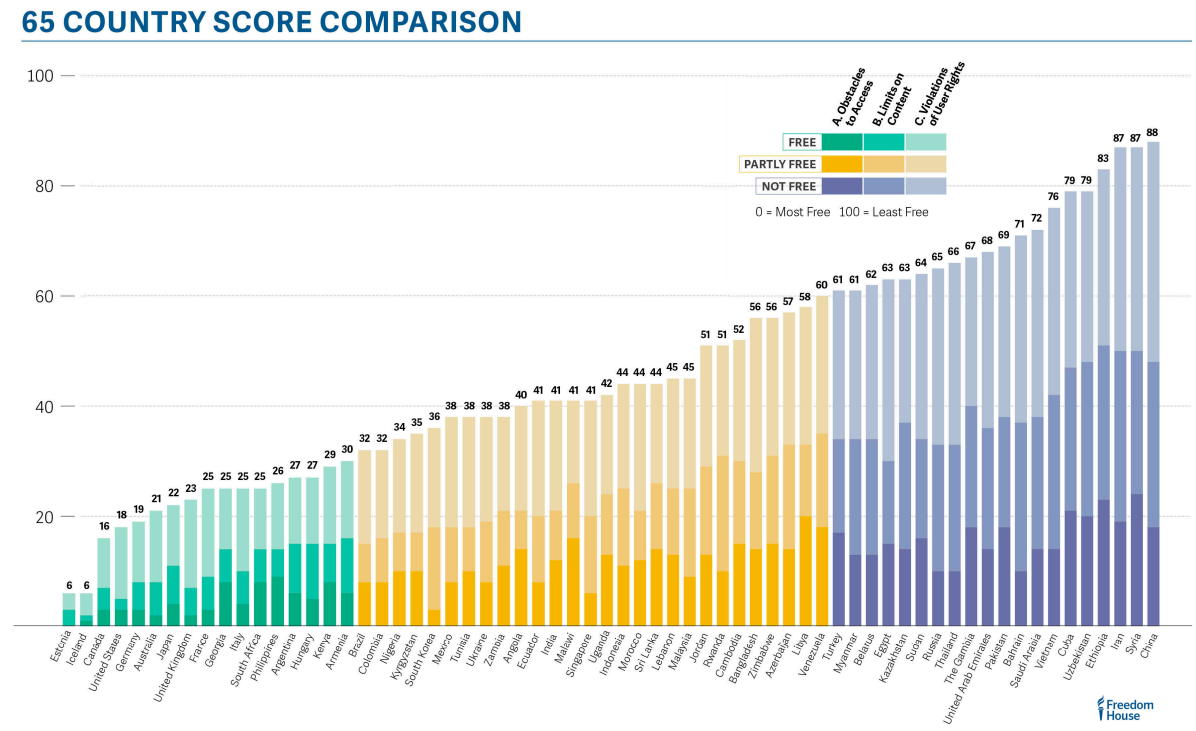

Figure 1. 65 Country Score Comparision (Freedom on the Net, 2016). 
In the last report on freedom on the Internet (the 2016 report, as the 2017 report had not been published while this study was being prepared), Freedom House ranked Estonia and Iceland as "the freest" countries with only 6 negative points. They were respectively followed by Canada with 16 points and the USA with foul points. Although it will be mentioned later, it would be beneficial at this point to note that:

Although the USA operates under a system of Common Law and Turkey operates with Civil Law as its legal system, particularly in terms of the 2015 IT regulations, Turkey used titles of "obscenity" and "child pornography" in a similar manner to the USA and introduced legislation to block access to this material on the Internet. Even though there are methodological differences, Freedom House criticized Turkey for making similar legal regulations. Because of these legal regulations, as well as other factors, Turkey declined from being "partly free" with 58 negative points in 2015 to being "not free" with 61 points in the 2016 report, in which the USA was regarded as one of the most free countries [8].

Furthermore, it is quite remarkable that, in the same report, Bangladesh with 56 negative points and Sri Lanka with 44 negative points were qualified as being "partly free", which was more free than Turkey.

\subsection{Background}

The reports and grades of the organization are also regarded as criteria for economic investments, besides "determination of the freedom rates". In other words, they are recognized as a mirror of the democracy and stability of the countries and are taken as the basis as to whether foreign investments should be made or not. Because the organization's structure has only been questioned in a limited number of studies/research, it is perceived that the reliability of the organization is "non-contestable".

Does this perception, therefore, reflect the truth? Or, is the American-based Freedom House, which is regarded as a reliable and prestigious organization, actually a part/supplement of the simulation of "the American Dream" that is used conceal America's-being claimed to have a "speculative" structure which is good enough to be "the astral" the simulation universe of Baudrillard in his "strict thesis" suggesting that we live in a world where nothing is what they look like, "power and authority war" on the world? The answer to this question can be found in the organization's structure.

\subsubsection{Foundations and Structure of the Freedom House}

In 1940, a group under the leadership of George Field from New York founded the "National Committee to Defend America by Aiding the Allies" (CDAAA) with the aim of attracting financial support for the USA during World War II. They achieved media coverage through their sensational propaganda, which soon drew the attention of Franklin Roosevelt and Wendell Willkie-two important presidential candidates of that time- as well as that of Eleanor Roosevelt (the first president of the UN Human Rights Commission later contributor to the Universal Declaration of Human Rights) - cousin of the former USA president Theodore Roosevelt and wife of Franklin D. Roosevelt. In 1941, Field and Willkie cooperated to establish Freedom House $[9,10]$ against the Nazi Braunhaus, which was Hitler's propaganda center in Munich.

According to the information on their website, Freedom House was founded by "the silent encouragement" of former USA President Franklin D. Roosevelt, and his rival in the 1940 elections Attorney Wendell Willkie and First Lady Eleanor Roosevelt became the first presidents (co-chairs) of the organization:

"Freedom House was established in 1941 in New York City. Its creation was a result of a merger of two groups that had been formed, with the quiet encouragement of President Franklin D. Roosevelt, to encourage popular support for American involvement in World War II at a time when isolationist sentiments were running high in the United States.

From the outset, Freedom House was notable for its bipartisan character. Its founders were a diverse group of prominent and influential Americans: journalists, business and labor leaders, 
academics, and former government officials. A key figure among its early leaders was Wendell Willkie, the Republican presidential nominee in 1940. Eleanor Roosevelt was also an ardent supporter and served, along with Willkie, as the organization's first honorary co-chair." [7].

The fact that, although it was frequently emphasized that the organization was independent of the political structure, as it was founded by First Lady Roosevelt and former president candidate Wendell Willkie with the encouragement of the USA President at that time, this shows that Freedom House cannot be considered to be completely independent from politics.

\subsubsection{Chairman and Staff of Freedom House}

The current Chairman of Freedom House is Michael J. Abramowitz, who previously worked as National Editor for the Washington Post, a White House reporter and was also a member of the Council on Foreign Relations and an executive board member of the National Security Archive after graduating from Harvard University.

However, in the past, Freedom House has had Chairmen that have had deep political connections within the United States. For instance, the chairman of the organization until 2010 was the former CIA Chef James Woolsey, who was one of the supporters of the Iraq invasion and the author of the book named "Sharia: The Threat to America" and who also suggested that Edward Snowden be executed [9].

After Woolsey, the neo-con David Kramer who was serving in the USA Foreign Affairs Department, assumed chairmanship of Freedom House [11].

The following chairman was Mark Przybyszewski, who was included in Secretary of State Colin Powell's team during "the emancipation" of Iraq-in other words, he had worked for the USA Foreign Affairs Department, and who trained in neo-con American Enterprise Institution. And as the former chairman did, Logan also selected one of the executives of Radio Free Europe founded by CIA in 1971 as the vice president.

It is seen that not only the chairman but many of the staff have previous connections to the USA Department of Foreign Affairs and CIA. For instance, in the 2015 Freedoms Report published by Freedom House, the six world leaders who were criticized (Russian Foreign Minister Sergei Lavrov, President of China Xi Jinping, Leader of the Coup in Thailand Prayuth Chan-ocha, Prime Minister of Hungary Viktor Orban, Vice President of Azerbaijan and President of Turkey Recep Tayyip Erdoğan) were emphasized as "the dictators". For such a harsh criticism, it is possible to express the irony of the fact the report, in which Azerbaijan Vice President's statement was quoted as saying "the CIA lies behind the Arab Spring", was signed by Arch Puddington, former chairman of Radio Liberty and Radio Free Europe, which were founded by the CIA for the purposes of anti-communist propaganda during the Cold War.

\subsubsection{Financial Structure of Freedom House}

According to the information on the website of Freedom House, the budget for 2015 was $\$ 10,771,374$, where $\$ 3,699,849$ of this amount was provided by the USA Government [12]. Furthermore, the budget for 2016 was $\$ 8,990,138$, with $\$ 2,792,152$ of it transferred by the USA Government [13].

The recent significant amount of funding by the USA Government to Freedom House has been described as "donation and aid". In particular, almost all the organization's budget for the years 2000-2003 (95\% of the budget) was provided by the USA Department of Foreign Affairs. Consequently, it can be said that the organization was financed almost completely by the USA Government [10].

Only a few simple sentences are enough to understand the relationship between the financial structure of the organization and the USA. In this regard, the financial structure of the organization has been built on "the donation and aids" provided by the USA Government, particularly the Department 
of State. Thus, is important to question how Freedom House can be "a non-governmental organization that is independent from the government-the USA Government".

As it is not economically and administratively independent as stated above, it should therefore be investigated how Freedom House can have a completely independent structure.

\subsubsection{Freedom House's "Advocacy" for the USA}

Because Freedom House is based on the original CDAAA, which aimed to attract financial support for the USA during World War II as well as its connection to former politicians (particularly figures from the USA State Department) and former CIA members (including the former CIA chef, as mentioned before) within its structure, this raises the question "Is it active for the sake of generating benefits for the USA?".

On the other hand, it becomes necessary to ask this question after observing that the organization was founded by figures from the CIA and the USA State Department who supported the Iraq invasion almost after a half century after the end of World War II; along with the fact that the organization also supports the claim that the USA "brought freedom and democracy to Iraq".

In addition other factors, the matter in question is whether democracy and freedom has actually been brought to the Middle East where many civilians lost their lives in a civil war created through strong "perception management". However, attention is drawn to the organization's sensitive attitude towards the USA State Department to see how Freedom House refers to those who express their opinion about this matter in its reports.

This perception management is not only limited to this context. By sharing photos/videos of children who have survived bombings in different locations around the world through the Internet in the regions of the Middle East that are under the control of the groups opposed to the USA, or in the regions that are under the control of the ruling groups supported by the USA, as well as the efforts to "prevent child porn", which is one of the basic reasons for Internet restrictions in USA (which will be mentioned later), it is possible to sensitiveness through the humanistic values, which can reach billions of people all over the world. Accordingly, it is asserted that the group supported by the USA is "right" and it is therefore necessary for the USA to bring democracy and human rights to the regions through that particular group.

In other words, concepts such as freedom, justice and democracy are regarded as important references for USA Foreign Policy. For instance, dissidents who protest against the ruling regime in their countries are invited to the USA and aim of this strategy is relay the message that "the USA is the motherland of freedoms" [14]. Nevertheless, it should be stated that the continuity of Middle East countries in particular is proportionate to how the USA perceives them and what contributions the USA makes for the regional policy while inviting the opponents [15]. Moreover, the hegemonic approach in USA Foreign Policy has shifted from a consent-based system into a forced system, and the USA - with passion to dictate its own policies-has shown a tendency to turn its back on international organizations and laws when it no longer supports them [16]. On this point, the famous communication theorist Chomsky give an example of how the USA interfered in Iraq, even though it was demonstrated under the supervision of UNSCOM that arms development in the region had decreased significantly before the interference. Chomsky stated that the law has a solution for these kinds of threats and emphasized that the law is also binding for the USA [17]. However, the perception that the USA is the advocate of "freedom and democracy" has now lost its plausibility [16].

The related literature also shows that Freedom House shows positive approaches towards "the USA-friendly countries" in addition to supporting the USA Foreign Policy in its reports-which is a political approach [11].

There is also the threat of "failing" in the freedoms for the countries in which the foreign policies do not correspond to the USA.

Justin Raimondo, editor of Antiwar.com, identified a similar approach on this point: “The USA government-funded organization known as 'Freedom House' has recently delivered a Christmas 
present to Russian President Vladimir Putin: his country has been downgraded, from 'partially free' to 'not free'. Israel, of course, is deemed completely 'free', in spite of treating its Arab subjects worse than Sparta ever treated its helots. Putin is no Jeffersonian democrat, but neither has he rounded up and imprisoned an entire people and sought to ethnically cleanse them from their homeland. Freedom House standards are elastic, bending to the dictates of American foreign policy" [18,19].

Accordingly, all the factors (foundation phase, presidents, current administrative structure, financial structure, advocacy for the USA) have led to suspicion that Freedom House is an organization that serves USA policy/foreign policy implemented by the USA government, the USA State Department and the CIA-rather than being an independent civil society organization working for the development of democracy and freedoms around the world.

The aforementioned provides a background on the establishment and operations of Freedom House. However, the following section will provide basic explanations related to the Internet-the control field of Freedom House, the auditor of freedom. In this regard, a brief history of the Internet will be firstly presented along with an explanation of the Internet in the context of mass media theories based on the example of the USA, as well as the concept of the Internet from theory to practice.

\section{Mass Media in Theory and Practice: "The Internet"}

\subsection{Creation, Development and Transformation of the Internet}

In the second half of the 20th century (in the late 1960s), a substructure was prepared for computers in of the majority of universities in the USA and studies were conducted to provide information about how they could be connected [20].

In 1972 and the following years, ARPA (Advanced Research Project Agency)—a governmental organization in the USA-performed various studies for military organizations and their demands. The attempts initiated by ARPA were proceeded to the next stage after the establishment of five super computer centers by the USA National Science Foundation in the 1980s.

Firstly, a net chain (ARPANET) was created to which the universities could connect [21]. Later, the "back bones" were added to the Internet in countries such as the USA and Japan in 1990 after the ARPANET was discontinued from operation.

Later, access to the Internet sources was facilitated by Minnesota University through its GOPHER system. Furthermore, in 1995, Netscape software executing transactions through the Web began to be used.

Sir Tim Berners-Lee, founder of the World Wide Web (WWW), encouraged that CERN to make the Internet accessible on a global basis without charge in 1993, with the support of those that held the same view that the Internet should not be under specific control or just belong to any specific group because of its emancipatory potential.

All these studies can be regarded as the beginning/keystones of "the digital era in communication" [22].

The development and transformation process of the Internet has still continued on the basis of the studies/developments briefly mentioned. Internet usage has increased exponentially, and thus, the Internet has become a significantly important mass media and has introduced a new field of freedom of expression.

Journalism on the Internet has become more widespread (digital newspapers and blogs). Furthermore, websites have been created that are commonly used today-such as e-mail providers (Hotmail, Yahoo, etc.), search engines (Google, etc.), websites for broadcasting and watching videos (YouTube, etc.) and social networking sites (Facebook, Twitter, etc.). Moreover, it has been observed that there has been increase in number of users [23].

The aforementioned increase in the number of Internet users can be seen as proof that the communication provided through this new technology surpasses that provided by previous mass media, such as the telegraph, telephone, newspaper and television [24]. 


\subsection{New Freedom of Expression Field from Theory to Practice: "The Internet"}

In his book titled "Understanding Media", McLuhan defines "the media" as an extension of ourselves-even as something that is directly connected to the nervous system in the human brain; furthermore, he states that people can perform tasks easier and faster by using tools or instruments than merely using their own bodies [25]. McLuhan states that the habit of group reading was broken when it became easier to obtain books individually after the invention of the printing press and thus, people became more asocial; however, he asserts that a new era started with the telegraph and people have started to become more social again [25].

McLuhan asserted that, beginning with the invention of the telegraph, each new form of mass media was revolutionary and developed or completely removed the previous invention, states that and this process would enable people around the world to communicate with each other as if they were living in a small village; thus, the world would become "a global village". The main question in his thesis was whether the state of "Texas" would be this global village, or through the global village, would "global citizenship" be achieved which has "a universal common view".

As a result of the Internet, it has become possible for people around the world to connect to one another instantaneously [4]. As in a small village, everyone can be aware about who is where, what they are doing and what they are thinking about through the posts they share on the social media. Hence, this raises the question of whether this global citizenship has a universal common view?

According to McLuhan, the main executives of our "global village" would be large international companies. Today, this hypothesis has almost become a reality, such that, when analyzed from specific to general (from our surroundings, to society, to other societies around the world and the whole picture of "all of us"), material goods such as glasses, watches, phones, computer, cars created by "those large companies" are used. We consume our beverages by "opening lids for happiness" or our fast-food by "hearing the voice of the fire calling us". We buy a mobile phone by "thinking differently" and when a new model is launched, we buy it even though our phone may be relatively new. In other words, we have become a "consumption society" rather than being global citizens that have a universal common view. Now, mass media exists, particularly the Internet (the latest and most effective).

On the other hand, Baudrillard defines the situation from a much "darker" perspective. He claims that everything in the world is made up of a "simulation". He states that the western culture has become "deadlocked" and is approaching the end, as with all deadlocked cultures. He also states that America - that represents many of the important aspects of western culture-is "a astral" in the universe of the simulations. Baudrillard mentions about his method in researching "America" by saying, "I researched about the Astral America; not the cultural or social America. I researched about America which displays nonsense and absolute freedom on its highways; not the deep America with customs and mindset. I researched about the America with its speed in desert, its motels and metal surfaces" [26].

The famous philosopher exemplifies his thesis (that we do not live in a reality, but in a simulation universe) with Disneyland in "America" that he defined as "the astral" of this universe. The Disneyland construct has the secret aim of making people believe that the outside world is real and is not a simulation [27]. While Disneyland is a "simulation", the rest is "real". "However, Los Angeles and America surrounding Disneyland do not belong to the reality but to simulation and hyper-reality" [27]. According to Baudrillard, the key point is that it is actually the real American that is being hidden in the simulation of Disneyland. In other words, America is a place where everything is constructed and nothing reflects the reality [27].

The strengthening and development of this simulative construct have been possible as a result of the mass media, along with other factors. In addition to the "informing" function, which was the primary aim of newspapers, the mass media has started to assume an "entertaining" function along with the changing structure of the media. This function has gained more power through the Internet (the most important mass media of this era) and social media. However, besides the functions of informing, training and entertaining, the media has secretly taken on the function of "perception management". In this regard, America's "reality of speculative freedoms" has 
been more widely engraved in modern perception along with the important effect of the Internet. Therefore, as mentioned previously, in the Middle East, military operations have been executed by the USA in the name of bringing "democracy and freedom", with photos and videos of small children who have survived in buildings destroyed by their opponents disseminated throughout the world through social media websites. All this content can be shared by users millions of times; thus, individuals have also become part of the perception management process, with access provided throughout the world — which might otherwise be almost impossible to achieve, even by spending billions of dollars.

On the other hand, there are also some opinions that state that the aforementioned new media and social media may be updated versions of öffentlichkeit (public sphere)—defined as the Bourgeois Public Sphere-which is a concept where the Bourgeois class make various decisions that have an effect on the formation of the laws regulating social life after debating these issues. This situation emphasizes the importance of communication through the Internet in the modern era [28,29]. In particular, the claim that there is still hope in "the Dark Picture" drawn by Baudrillard—which has largely been proven to be true in modern times-is significantly supported by the possibility that the social media may be a new public sphere. In this context, besides the perception management they are exposed to, users of the social media around the world can post and discuss their own views about social events, and these discussions could affect the decisions made by individual countries or even on a global scale. This claim becomes stronger, particularly in the context of posts and discussions about documents related to wars or "weapon barons", and posts regarding important documents that the USA and many other countries want to remain confidential. While, there is the case for protecting democracy and freedom of expression on the one hand, on the other hand, there could sometimes be censorship imposed on all of these discussions even though they are not disturbing the peace and/or they are not "confidential documents" in the legal sense.

The gradually increasing tendency mentioned above-in other modern words, the increasing popularity of the Internet and the aforementioned views (that the Internet forms the basis of the global world, or that it is an important media in the simulation universe, or that it is something new that could be accepted as a new public sphere)—has led to questions about why the Internet is used (for example, in a positive way, just for communication, for socializing, social/global discussions, informing/getting information, etc.; or for weakening political authority(ies), removing them, creating turbulence in country(ies), for accessing other people's private information without permission, or for sharing anti-ethical posts, etc.). This can be done if the related attempt (post/publications share for a significant aim) is basically against the freedom of expression; and censorship can only be implemented if there are previously prepared regulations regarding the issue through a court decision; of course, the application of censorship differs from country to country.

\section{Example of the USA}

\section{1. "Center of Simulative Freedom"}

As a result of the research conducted by Freedom House based on countries around the world, it was declared that the "freest" countries on the Internet were Estonia and Iceland, with only 6 negative points. In the rankings published by the organization, Iceland was listed immediately after Estonia. In the research, it was claimed that the USA is "a quite free" country on the virtual platform, with 18 negative points-as was the case in most of the research conducted by Freedom House.

The USA, on the surface, generally implements "an emancipatory" policy in terms of access and usage of the Internet; "the free Internet" has had significant importance, not only for the country, but also for its foreign affairs for many years. This approach is expressed as "encouragement for providing online protection for human rights as much as offline protection". 
Through the same approach, in order to create a platform on the Internet that is open for learning and communication, it is stated that the aim of the USA (authorities) is to provide "a universal (global) Internet environment" which is free from illegal bans or restrictions.

According to the watchdog organization Freedom House, while freedoms on the Internet have decreased globally over the last three years, various studies have been conducted to provide "assurance" a term that was defined by the former USA President Barack Obama as "supporting open access to the Internet and the right to be heard of the journalists (working for a large news organization or being just a blog author)".

The USA frequently claims that, as a government policy, they are conducting studies intended to provide freedom of the Internet, not only intrastate, but also in other countries. Furthermore, the increasing number of websites being censored is given as the reason behind these studies: China and Iran have censored thousands of websites, including news sources and social media. Turkey, having restricted access to Twitter and YouTube, also performed censorship on the Internet.

Referring to all these matters, the USA Secretary of State Kerry stated in a Freedom Online Conference that, "... the main difference is that we create the freedom of expression everywhere-including our allies-where it is at risk. This is the reason why we issued a call for Turkey to remove the Twitter block and all other blocks against the freedom of expression on the Internet ... " [30].

According to the Freedom on the Net Report published by Freedom House in 2013, 25 countries had introduced new negative regulations related to online freedom of expression since the previous annual report had been published.

Austria, Belgium, Greece, Ireland and Spain are some of the EU nations were there are no regulations/laws related to Internet bans. Likewise, in some non-EU nations such as Switzerland, Iceland and Liechtenstein, no laws have been made regarding Internet bans until this point either. On the other hand, Denmark, France, Finland, Italy, Netherlands and United Kingdom are some of the EU nations that have made decisions related to Internet ban and have put them into practice; the non-EU nations Norway and Sweden also have laws related to bans. When the reasons behind these kinds of laws are examined, it is seen that the benefits of the EU and the wider society are prioritized.

For instance, the Swedish parliament passed an act in 1998 called the Responsibility for Electronic Bulletin Boards, which included measures against racist provocations and agitations on the Internet. Thus, it can be seen that racism and racist provocations led to the introduction of an Internet ban in Sweden [31].

Referring to all these matters, Secretary of State Kerry said that, " . . w we believe in providing people's voice to increase from the bottom to the top. However, supporters of authority consider the free, open and inclusive Internet as a threat to governmental power. They use their power to threaten the Internet. And the aim of this is to control the information and access to the information from top to bottom ... " [30].

The USA authorities frequently make determinations related to freedoms/freedom of the Internet in other countries and issue warnings accordingly. This approach displayed by the USA, as mentioned before, is based on its strategy to adopt it as a government policy. This strategy is supported by Freedom House as it portrays America as one of the most developed countries in the world in terms of democracy and human rights, as well as freedom of the net.

However, other factors (that will be mentioned later in this study) indicate that the situation in the USA is not as positive as it has portrayed in the Freedom House report, as there are critical problems related to freedoms of the Internet. Consequently, this implies that the USA does not have the moral right to interfere in other countries.

On the other hand, the USA is one of the founding members of the Freedom Online Coalition, which forms a structure in which 23 governments collaborate to develop freedom of the Internet all over the world.

In the last 5 years, with the purpose of supporting the projects implemented to contribute to global freedom of the Internet, the USA has invested over $\$ 125,000,000$. These projects have been implemented with to the intention of supporting reliable communication technologies which are against censorship, promote digital safety trainings, "advocacy of the politics" and innovative research. 
On the other hand, the USA also contributes to "the Digital Defenders Partnership", which provides immediate support to defenders of human rights, journalists, blog writers and activist organizations that experience problems related to freedom of the Internet [30].

In summary, almost all the text on the USA Government website having been referred as source generates a form of "perception management" in favor of the USA by stating that the Internet in the USA is very free; furthermore, the USA makes investments to ensure global freedom of the Internet. It is not clear from the text what "the advocacy of politics" exactly means-which is presented as a reason why the USA maintains an attitude towards global freedom of the Internet; nevertheless, the likelihood is that it has the aim of "spreading pro-American policies". This alone can be interpreted to mean that freedom of the Internet is not only used for contributing to the freedom of expression, but also for disseminating pro-American policies.

\subsection{Awakening from "The American Dream"}

While the "rosy picture" drawn by the politicians/USA authorities about freedom of the Internet in the USA is examined, it is stated that the practices related to freedom of the Internet are similar to the political approach. Nonetheless, when the court decisions in the United States are analyzed, it is seen that the situation does not always conform to the expectations. Here is a related example:

"As a matter of constitutional tradition, in the absence of evidence to the contrary, we presume that governmental regulation of the content of speech is more likely to interfere with the free exchange of ideas than to encourage it. The interest in encouraging freedom of expression in a democratic society outweighs any theoretical but unproven benefit of censorship". [32]

The aforementioned approach emphasizes the importance of "the freedom of expression" and also mentions "the theoretical but non-proven benefit of the censorship".

It is emphasized that the court decisions made about the Internet restrictions in the USA have largely been regarding "obscenity", "child porn" and "chance games played through the Internet".

This raises the question, why would the USA restrict online gambling through the Internet while there is "Las Vegas"—a city that almost completely based on the concept of gambling? It is nearly impossible to find this question in any source. Aside from "the positive view" asserting that this restriction is intended for "using the Internet just for accessing information/communication", and for providing the freedoms within this scope, there is also a critical assumption that the USA chooses to restrict the online gambling websites created by organizations from other countries to be played through the Internet, and it aims to "prevent" the tendency of users moving towards the organizations from other countries instead of Las Vegas, the city of entertainment and gambling".

After "the Internet Gambling Prohibition Act" (for "protection of those playing chance games on the Internet from crime and abuse") came into effect in 1999 in the USA-which is one of the restraint decisions that instigated significant debate-the fact that some measures were taken because of the fact that the relationship with other countries was damaged [31] supports the second assumption.

On the other hand, while an emancipatory approach is always displayed in political discourse and it is "always" emphasized that the USA is "the country of freedoms", "the Communications Decency Act" that came into effect previously sets an example that the legitimatized issues are not always of a similar nature.

After the applicable law was introduced (8 February 1996), about 50 complaints were submitted to the Attorney General, claiming that it was an unconstitutional statue-particularly Article 223 (a) and Article 223 (d). The District Court, with three judges, reached a verdict that declared both articles be removed; and they construed that the articles did not clearly explain the definition of the phrases "obscene" and "over-aggressive" and defined them to be "unclear", and they found them to be unconstitutional. The government objected to the decision and argued for maintaining the practice of articles mentioned. Moreover, they asserted that the decision was not correct. 
Later, the Child Online Protection Act of 1998 (COPA), described as the son of the "Communications Decency Act", came into effect. This law-prepared as a more limited version of the CDA—was also criticized; it was reviewed in courts in various states on the basis of its unconstitutionality. As a result of the related court cases, COPA was deemed to be unconstitutional.

Of particular importance was the case of Mainstream Loudoun et al. vs. Board of Trustees of Loudoun County Library et al., in which the judge found that the act was unconstitutional for being "against the freedom of expression", as well as the case of Reno v American Civil Liberties Union, in which the judge made a decision to stop the practice of the related law.

Furthermore, a federal case was brought to the Supreme Court; and a lower court decision was brought to III. Supreme Court of Appeal of the USA. In both cases, it was stated that the standards for material that was required to be blocked from general viewing were clearly defined, and the content which might not be suitable for children up to 4 years of age might hide behind the age validation firewall [33]. In the related issue that was brought before the Supreme Court on two occasions, the opposing party claimed that access to websites could be blocked merely because a small advertisement contains obscenity, because this situation would be against the freedom of expression.

This issue was mentioned in the 2015 report published by Freedom House about freedom of the Internet in the USA:

"Congress has passed several laws designed to restrict adult pornography and shield children from harmful or indecent content online, such as the Child Online Protection Act of 1998 (COPA), but these laws have been overturned by courts due to their ambiguity and potential infringements on the First Amendment of the U.S. Constitution, which protects freedom of speech and the press" [34].

Although the responsible approach and abolishment of the law by courts is mentioned briefly in the report, there is no information presented to explain that the reason why the law was abolished was because it was against the constitution, the freedom of expression and thus, freedom of the Internet.

On the other hand, bans are generally not imposed on "religious", "political", "ideological" and/or "scientific" studies. Nevertheless, in the same country, in some states, it is quite ironic that a "cross" is located on the wall directly behind the judge(s) that everyone in the court (defendant, complainant and lawyers) can see. While freedom has significant importance, even in the virtual platform, using "religious" and "ideological symbols in the courts, which are expected to be independent and unbiased, can create both "suspicion" regarding the independence of the courts, and oppress people attending the court (particularly those accused of crimes) who have different religious faiths or ideologies. Thus, it can cast suspicion and reduces their trust in the judicial system and their sense of freedom. Whereas, in the law, which puts the social issues in order, "integrity and equality" are the underlying principles. Criticizing this situation is related to this subject in terms of the freedoms; nevertheless, further emphasis will not be placed on this subject in the context of this study because the principal focus is on freedoms in the Internet environment. However, it will be researched in a future study.

Again in the USA, Wireless Communication and Public Safety Act that came into effect in 1999 contains a regulation concerning pornographic materials that are broadcast on online platforms and has the aim of removing/blocking obscene and inappropriate content.

After that, the Children's Internet Protection Act (CIPA) - which has the aim of blocking and filtering specific parts of websites containing child pornography and other harmful contents for minors-came into effect in 2000.

After the related law (CIPA) came into force in 2000, it became compulsory for public libraries to install Internet Filter Software onto their computers in order to qualify for federal funding. The American Library Association and others claimed that the constitutional rights of the users were restricted, and they objected to the law. The District Court heard the case and determined that the CIPA violated the First Amendment.

Later, the decision by the District Court was brought to the American Supreme Court. As a result, it was stated that the law proposing that public libraries use filter programs was not unconstitutional, 
and the Congress was entitled to make legal reforms about financing of the public libraries in the related matter. Therefore, the decision of the District Court was overturned.

It was written in the report published by Freedom House about the related act as follows:

"One law currently in force is the Children's Internet Protection Act of 2000 (CIPA), which requires public libraries that receive certain federal government subsidies to install filtering software that prevents users from accessing child pornography or visual depictions that are obscene or harmful to minors. Libraries that do not receive the specified subsidies from the federal government are not obliged to comply with CIPA, but more public libraries are seeking federal aid in order to mitigate budget shortfalls. Under the U.S. Supreme Court's interpretation of the law, adult users can request that the filtering be removed without having to provide a justification. However, not all libraries allow this option, arguing that the decisions about the use of filters should be left to the discretion of individual libraries" [34].

In the report, there was nothing mentioned about the fact that the act was criticized and brought before several courts because of the components that were contrary to the freedom of expression and freedom of the Internet-even though the main focus of the report was about the freedom of expression.

On the other hand, Freedom House displayed an attitude towards Turkey, who introduced similar laws 2015, that was completely different to the attitude it exhibited towards the USA in the same report. In the following year, it graded Turkey as "not free", whereas it had been "partly free" previously. This attitude can be quintessentially called a "double standard".

Also, another factor to be emphasized is "the ICANN". ICANN (Internet Corporation for Assigned Names and Numbers) is a non-governmental organization which has right to access various information, such as whether e-mails are received by the correct persons, whether users surf on the Internet, whether they have shared any posts, etc. Furthermore, it also assures the related matters. Nevertheless, "the final word" about all these matters belongs to the USA Department of Commerce. Without the "permission" of the NTIA—the National Telecommunications and Information Administration affiliated to the Ministry of Commerce-it is impossible to do anything on the Internet.

As a result of continual demands to change the situation, the USA authorities declared that they wanted to delegate their authority over domain names to an independent organization in 2014. Although studies were conducted and it was stated that an agreement between ICANN and the USA Department of Commerce would be finalized on 1 October 2016 [35], no changes related to this point have been implemented yet.

Nevertheless, significant emphasis has not be placed on this point. It shows that the Internet for all countries around the world is under the control of ICANN and therefore, indirectly, the USA Department of Commerce. In this regard, it is worth repeating that it is a striking truth that it is "impossible to do anything on the Internet" without the permission of the United States, and all the processes in the virtual environment are implemented and will continue to be implemented under the control of the USA.

Even though minimal details are provided, it is stated on the website of Freedom House in relation to this point that:

"In response to the U.S. National Telecommunications and Information Administration (NTIA) decision to support the global internet community's proposal to fully privatize oversight over the key functions that control the Domain Name System (DNS) and allow data to be sent among connected devices, Freedom House issued the following statement: "NTIA's announcement brings us another step closer to ensuring that the internet remains an open platform not dominated by a single entity - whether it be a government, the private sector, or any other force," said Sanja Kelly, director of the Freedom on the Net project. "The current U.S. government oversight of the central DNS functions is largely symbolic but has given authoritarian regimes cover for demanding greater regulation of the internet through the UN and other international bodies. The current plans for privatization include strong safeguards to prevent that from happening, but close public 
attention will remain critical to make sure the plan unfolds as intended". Background: The U.S. government has held formal control over key DNS functions through a contract between NTIA and the non-profit Internet Corporation for Assigned Names and Numbers (ICANN). In March 2014, the United States announced its intention to transition its oversight role to a global multi-stakeholder community. Now that NTIA has signed off on the transition plan, ICANN has until mid-August to address outstanding issues identified in NTIA's review. The contract between ICANN and NTIA expires at the end of September. The final decision on ending the agreement is expected by the end of August. The United States is rated Free in Freedom in the World 2016, Free in Freedom of the Press 2016, and Free in Freedom on the Net 2015" [36].

Although concrete steps have not been taken by the USA authorities based on these criticism and demands, in 2014, it was claimed that "there will be studies carried on just this point"; however, no changes have been observed in the following period and Freedom House states that the powers are merely symbolic. Later, it emphasized that there has been declared that powers will be delegated, even though they are important, and it has not criticized the situation or the long-term delay. Finally it emphasized that the USA is one of the countries with freedom of the Internet, and thus, the sub-text of this message (so to say) is that there would be no problem in terms of the freedoms if this mechanism was under the control of the USA.

On the other hand, it is also important to mention Net Neutrality, because of its relationship to the subject of this study. This is the principle that Internet connectivity cannot be managed by service providers and/or governments. In this respect, an external power should not be able to adjust the Internet connection in accordance with the actions performed on a computer. Namely, within the scope of the principle, an Internet provider cannot determine the bandwidth according to the server used. Furthermore, it cannot even examined which applications have been used and the governments cannot restrict access to any Internet website by any means.

However, if filtration is applied because material is unconstitutional, this must be "transparent". Broadband providers must explain consistently the reason why such restrictions are applied. Furthermore, it is necessary for the governments to prevent the wide-band providers to ban and restrict arbitrarily [37].

The first country in the world which adopted Net Neutrality was Canada. Subsequently, in Europe, the Netherlands adopted the principle and assured its people that there would be no restrictions.

In terms of the USA, it has been emphasized that Net Neutrality was a concept proposed by Former President Obama, concrete steps were taken accordingly. In this respect, Net Neutrality was confirmed by the Federal Communications Commission (FCC), which is an independent government department responsible for supervising interstates and international radio, television, telephone, satellite and cable communication within the USA. This situation was defined as a victory for millions of people by President Obama [38].

However, as there is a mechanism giving the management of all the processes about the Internet to the USA, the adoption of Net Neutrality has significant importance in terms of freedoms of the Interne in the USA as well as in all other countries.

It should also be stated that the USA requested data on approximately 31,000 users from Google in 2012. In these requests, Google rarely received a search warrant. This supports the claim regarding how "aggressive" the USA is in its attempts to obtaining virtual data [39].

The USA claims that they make all of these requests in the interest of protecting intellectual property rights, preventing cyber-attacks and child pornography, and protecting national assets, such as nuclear power plants, from hackers. Additionally they also claim that restrictions or censorship on freedoms of the Internet is necessary.

Freedom House mentioned this point in their related report as follows:

"A number of democratic states have considered or implemented various restrictions in response to the potential legal, economic, and security challenges raised by new media" [40,41]. 
In the 2016 report, Freedom House stated once more that the USA did not censor the political and social content, and only restricted content that contained obscenity, child pornography and illegality (such as copyright, etc.):

"The government does not censor any particular political or social viewpoints, although legal rules do restrict certain types of content on the internet. Illegal online content, including child pornography and content that infringes on copyright, is subject to removal through a court order or similar legal process if it is hosted within the United States" [42].

Also, it should be stated that draft laws called the Stop Online Piracy Act (SOPA) and the Protect IP Act (PIPA) came to the fore in the USA Senate in 2012. As there would be crucial alterations related to the Internet in the USA and all over the world if the draft passed into law, mainly in terms of copyrights, it was debated extensively. It was criticized harshly by organizations such as Google and Facebook on the grounds that it would violate freedoms of the Internet and many online posts were shared criticizing it. Consequently, the draft laws were not approved.

While preparing this study for publication, the statements in the last report (2016) of the Freedom House related to the USA, on freedoms of the Internet were reviewed:

"The USA FREEDOM Act passed in June 2015 limited bulk collection of Americans' phone records and established other privacy protections. Nonetheless, mass surveillance targeting foreign citizens continues through programs authorized under Section 702 of the FISA Amendments Act and Executive Order 12333" (see Surveillance, Privacy, and Anonymity)[8].

In the further paragraphs of the report, it is mentioned of that there will be request of supervision anymore in the courts where was emphasized on "behind the closed doors" while asking for the phone records related to this point. When it is considered in term of prevention of some confidential records to be come out via the court, it would be concluded that this situation corresponds with the main mission of the Freedom House-mentioned under the title of "background".

Online media outlets and journalists face increased pressure, both financially and politically, that may impact future news coverage (see Media, Diversity, and Content Manipulation [8].

Following a terrorist attack in San Bernardino in December 2015, the FBI sought to compel Apple to bypass security protections on the locked iPhone of one of the perpetrators (see Surveillance, Privacy, and Anonymity) [8].

In these two areas, the USA was criticized in a limited way. On the other hand, the new President Donald Trump was mentioned in the report and his attitude towards the media was criticized. However, in the further paragraphs of the report, it was stated that access to the Internet is generally transparent and independent of the government in the USA. Even though it was emphasized in the report that the censorship intentions of some politicians and businessmen on their opponents' views creates anxiety, there was no significant decrease in the score for the USA regarding freedoms in comparison to the previous year.

\section{Conclusions}

In the world of the 21st century, which verifies the "global village" thesis of McLuhan, discussions about advantages and disadvantages of the Internet are ongoing. In terms of the advantages of the Internet, it is argued that awareness of the Internet should be raised through discussions on social and/or universal matters by creating a system similar to Habermas' Public Sphere; thus, it would be possible to achieve positive results. Furthermore, in terms of the disadvantages of the Internet, it is claimed that harmful contents on the Internet violate the right of privacy as well as moral rights, and can have a damaging/destroying impact on ruling governments in countries. Censorship of illegal contents is still regarded as the most effective method. 
On the other hand, it should be primarily stated that issues of access to the Internet and freedoms are regarded differently in different regions (countries) based on the political and legal differences, lifestyles, social values and different approaches of the elected politicians.

It is seen that the political and legal approaches in the countries are in parallel (if not in terms of discourse, but in terms of action).

Referring to this point, in the example of the USA that was analyzed in this study, it can be seen that certain practices in the country contradict with the claims regarding access to the Internet and freedoms of the Internet; even if the country is ranked at the top of the list in terms of being "the freest", and the politicians frequently emphasize that freedoms of the Internet are important goals, both in the USA and around the world.

As has been stated, while the politicians consistently emphasize the importance of the free Internet, their tendency differs in Congress, where they and their respective parties are responsible as protectors of the law. Legislation has been enacted that has considerably restricted democracy and freedom of expression. This leads to "arbitrary" practices that are rather different to the general discourse.

Regulations related to restricting the freedoms are generally related to "child pornography" and "obscenity". Nevertheless, this are also incorrectly used for restricting individuals' freedom of expression. In regard to the decisions made by the courts related to the abolishment of the aforementioned regulations, the USA government generally displays a "dissatisfied" approach, and even claims that "the courts are in the wrong".

As Baudrillard claimed in his thesis on the "simulation universe", "America" defined as the astral of that universe, is introduced (through some simulations which hide "the real intention") as one of the most developed countries of the world-even the most developed-in terms of democracy and human rights. On the other hand, it has a structure where censorship does exist to a considerable extent, where efforts continue to legislate the censorship through the laws, and where politicians react "too strongly" when the related laws are abolished by the courts because their unconstitutional contents.

The reality behind the simulation is not just about this: In accordance with the agreement between ICANN and the USA Department of Commerce, the USA-regarded as supervising the control mechanism that controls the Internet on behalf of the entire world and receiving criticism because of this fact, has not moved to end this agreement. After the expiration of the agreement, it is necessary to make the management of the Internet independent; to make the regulations in a way that does not obscure freedoms which represent one of the key elements in the USA Constitution by considering the benefit of the society; and to encourage politicians to display attitudes as the executives of a country which is regarded as the motherland of democracy and human rights in the world-not to act as the executives of "the high power".

Also, it is seen that the aforementioned USA-based Freedom House, which publishes reports about freedoms of the Internet, and makes evaluations on more than 60 countries in those reports, is not sufficiently "objective" in its approach.

While defining the American authorities as emancipatory in terms of their political discourses about freedom of the Internet, Freedom House does not criticize the legal regulations damaging freedoms in the USA-apart from some exceptions. In fact, it makes criticisms when the related regulations are abolished by American courts because they are considered to be against the freedom of expression. Moreover, it mentions in its reports that the matters legislated by the USA Senate with "high awareness" are "got rid of" by the courts; and it ranks the USA at the top of the category of "the freest countries".

Although Freedom House claims to be an independent non-governmental organization, it is seen that it is not actually independent from the USA government-instead, it is "an instrument" used by the authorities in that country. This is because it has had a political structure since its inception; for example, even a former CIA Chief has presided over the organization as chairmen, it is supported by the USA financially and it "defends and supports" the USA in terms of its foreign policies. America, the astral of the simulation universe of Baudrillard, uses instruments to make others believe 
in "the American Dream" and maintains its perception management in this manner. Freedom House is one of the important instruments in this respect and it serves the benefits of the USA and the ideal of "the high power" to administer the whole world. This situation is unacceptable for an organization recognized as having "universal prestige" on freedoms of the Internet. Unless this organization becomes independent of the USA both financially and executively, it will not be possible to change this situation.

Author Contributions: Ayhan Dolunay conceived of the concept of the article and wrote the article; Fevzi Kasap provided conceptual input and commentscontributed to writing/revising main parts of the article; Gökçe Keçeci contributed to data collection and data analysis.

Conflicts of Interest: The authors declare no conflicts of interest.

\section{References}

1. Baştürk, E. Demokratik devletin gerekleri ve Türkiye. Liberal Diuşünce Dergisi 2011, 16, 49-60.

2. Ural, Ş. Demokrasi kavramı, toplumsal değerler ve birey. Ankara Üniversitesi İlahiyat Fakültesi Dergisi 1999, 40, 451-459.

3. Kavra, E. Montesquieu ve de Tocqueville'e göre demokrasi ve temel güvenceleri. Amme İdaresi Dergisi 1989, $22,75-83$.

4. Tonta, Y.; Çelik, A. Düşünce özgürlüğü, bilgi edinme özgürlüğü ve bilgi hizmetleri. In Bilgi edinme özgürliüğï; Türk Kütüphaneciler Derneği Ankara Şubesi: Ankara, Turkey, 1996; pp. 1-13.

5. Bozkurt, E.; DOST, Ö.G.S. Avrupa İnsan Hakları Mahkemesi Kararlarında İfade Özgürlüğü ve Türkiye. Süleyman Demirel Üniversitesi İktisadi ve İdari Bilimler Fakültesi Dergisi 2002, 7, 47-74.

6. McPherson, J.M. Abraham Lincoln; Oxford University Press: Oxford, UK, 2009.

7. About Freedom House. Available online: https://freedomhouse.org/about-us (accessed on 10 December 2016).

8. Freedom on the Net, October 2016. Available online: https://freedomhouse.org/sites/default/files/FOTN_ 2016_Full_Report.pdf (accessed on 4 January 2017).

9. Oğur, Y. Özgürlük Evi'nde Kısa Bir Gezinti. 5 June 2014. Available online: http:/ / m.marmarayerelhaber. com/Yildiray-OGUR/24662-Ozgurluk-Evinde-kisa-bir-gezinti (accessed on 5 May 2017).

10. Barahona, D. The Freedom House Files; Monthly Review Zine; Monthly Review Foundation: New York, NY, USA, 2007.

11. Steiner, N.D. Testing for a political bias in freedom house democracy scores: Are USA friendly states judged to be more democratic? J. Comp. Policy Anal. 2012, in press. [CrossRef]

12. Financial Report 30 June 2015. 8 February 2016. Available online: https:/ / freedomhouse.org/sites/default/ files/FreedomHouse_15FS_Final.pdf (accessed on 20 May 2017).

13. Financial Statements Year Ended 30 June 2016 and Independent Auditors' Report. 31 January 2017. Available online: https:/ / freedomhouse.org/sites/default/files/FINAL_Basic_Financial_Statements_2016.pdf (accessed on 21 May 2017).

14. Sümer, G. Amerikan Diş Politikasının Kökenleri ve Amerikan Diş Politik Kültürü. Uluslararasi Iliskiler 2008, 5, 119-144.

15. Oğuzoğlu, T. Arap Baharı ve Yansımaları. Ortadoğu Analiz 2011, 3, 8-16.

16. Çiftçi, K. Soğuk Savaş Sonrasında ABD: "Rıza"ya Dayalı "Hegemonya"dan “İmparatorluk" Düzenine. Zonguldak Karaelmas Univ. J. Soc. Sci. 2009, 5, 203-219.

17. Chomsky, N. Sam Amca Ne İstiyor. Minerva yay 2000, 1, 13.

18. Raimondo, J. The Devil's Christmas. 24 December 2004. Available online: http://original.antiwar.com/ justin/2004/12/24/the-devils-christmas/ (accessed on 25 May 2017).

19. Freedom House. 1 July 2011. Available online: http://rightweb.irc-online.org/profile/freedom_house/_edn13 (accessed on 29 May 2017).

20. Vural, Z.; Bat, M. Yeni Bir İletişim Ortamı Olarak Sosyal Medya: Ege Üniversitesi İletişim Fakültesine Yönelik Bir Araştırma. J. Yasar Univ. 2010, 5, 3348-3382.

21. Timisi, N. Yeni Iletişim Teknolojileri ve Demokrasi; DOST KITABEVI: Ankara, Turkey, 2003; ISBN 9752980481.

22. Briggs, A.; Burke, P.; Şener, İ. Medyanın Toplumsal Tarihi: Gutenberg'den Internete; İzdüssüm Yayınları: Istanbul, Turkey, 2004. 
23. Avşar, Z.; Öngören, G. Bilişim Hukuku; Türkiye Bankalar Birliği: Istanbul, Turkey, 2010.

24. Babacan, E.M.; Haşlak, İ.; Hira, İ. Sosyal Medya ve Arap Baharı. Akademik İncelemeler Dergisi 2011, 6, 63-92.

25. Rigel, N. (Ed.) Kadife Karanlık (21. Yüzyıl İletişım Çă̆ını Aydınlatan Kuramcılar); Su Yayınları: İstanbul, Turkey, 2005.

26. Baudrillard, J. Amerika,(Çev. Yaşar Avunç); Ayrıntı Yayınları: İstanbul, Turkey, 1986.

27. Baudrillard, J.; Adanır, O. Simülakrlar ve Simülasyon; Dokuz Eylül Yayınları: Ankara, Turkey, 1998.

28. Valtysson, B. Facebook as a digital public sphere: Processes of colonization and emancipation. J. Glob. Sustain. Inf. Soc. 2012, 10, 77-91.

29. Papacharissi, Z. The virtual sphere: The internet as a public sphere. New Media Soc. 2002, 4, 9-27. [CrossRef]

30. ABD'nin Özgür İnternete Verdiği Destek Hakkında Bilmeniz Gereken 10 Şey. 29 May 2014. Available online: http:/ / photos.state.gov/libraries / istanbul/231771/PDFs/ScottBusby-USSupportforInternetFredom_TR. pdf (accessed on 15 December 2016).

31. Bulut, E.A. Türkiye'de internet yasakları. Bilgi Dünyası 2009, 10, 163-185.

32. Reno, Attorney General of the United States, et al. vs. American Civil Liberties Union et al. 1997. Available online: https:/ / supreme.justia.com/cases/federal/us/521/844/case.pdf (accessed on 25 December 2016).

33. Child Online Protection Act Overturned. 29 July 2008. Available online: http://abcnews.go.com/Technology/ AheadoftheCurve/story?id=5428228\&amp;amp;page=1 (accessed on 23 December 2016).

34. United States. 2015. Available online: https://freedomhouse.org/report/freedom-net/2015/united-states (accessed on 5 March 2017).

35. İnternetin Kontrolü Amkerika'dan Çıkıyor. 20 August 2016. Available online: http:/ /www.gazeteduvar. com.tr/teknoloji/2016/08/20/internetin-kontrolu-amerikadan-cikiyor/ (accessed on 5 January 2017).

36. U.S. Moves to Privatize Oversight of Internet Domain Name System. 10 June 2016. Available online: https: / freedomhouse.org/article/us-moves-privatize-oversight-internet-domain-name-system (accessed on 5 January 2017).

37. Nunziato, D.C. Virtual Freedom: Net Neutrality and Free Speech in the Internet Age; Stanford University Press: Palo Alto, CA, USA, 2009.

38. Net Neutrality, President Obama's Plan for a Free and Open Internet. 14 June 2016. Available online: https:/ / obamawhitehouse.archives.gov/node/323681 (accessed on 20 May 2017).

39. Warf, B. Geographies of global Internet censorship. GeoJournal 2011, 76, 1-23. [CrossRef]

40. Big Brother? USA Linked to New Wave of Censorship, Surveillance on Web. 21 February 2013. Available online: http:/ / www.foxnews.com/tech/2013/02/27/special-report-surveillance-and-censorship-america. html (accessed on 25 December 2016).

41. Freedom on the Net, 2012. 24 September 2012. Available online: https://freedomhouse.org/sites/default/ files/FOTN2012FINAL.pdf (accessed on 5 January 2017).

42. United States. 2016. Available online: https:// freedomhouse.org/report/freedom-net/2016/united-states (accessed on 20 December 2016).

(C) 2017 by the authors. Licensee MDPI, Basel, Switzerland. This article is an open access article distributed under the terms and conditions of the Creative Commons Attribution (CC BY) license (http://creativecommons.org/licenses/by/4.0/). 